\title{
İş Dünyası ve Üniversiteler Arasındaki İş Birliği ve Stratejik Yönetimi
}

\section{Cooperation and Strategic Management Between Business World and Universities}

\author{
Mehmet Naci Efe ${ }^{a^{*}}$ \\ ${ }^{a}$ Dr. Öğr. Üyesi, Üsküdar Üniversitesi, İ̈BF, İşletme Bölümü, 44280, İstanbul/Türkiye \\ ORCID: 0000-0002-9906-7349
}

\section{MAKALE BILGGISİ}

\section{Makale Geçmişi:}

Başvuru tarihi: 12 Şubat 2019

Düzeltme tarihi: 15 Şuba 2019

Kabul tarihi: 18 Şubat 2019

\section{Anahtar Kelimeler:}

Yönetim

Stratejik Yönetim

Üniversite

İş Birliği

\section{A R T I C L E IN F O}

\section{Article history:}

Received 12 February 2019

Received in revised form 15 February 2019

Accepted 18 February 2019

\section{Keywords:}

Managament

Strategic Managament

University

Cooperation

\section{ÖZ}

$\overline{\mathrm{Bu} \text { araştırmanın amacı, iş dünyası ve üniversiteler arasındaki iş birliği ve stratejik yönetimi }}$ kavramsal olarak ele alıp, incelemektir. Bilim ve teknolojide yaşanan gelişmeler sonucunda firma ve kuruluşların ihtiyaçları değişmektedir. Bu da bu yeniliklere ayak uydurabilecek mesleki ve teknik kalifiye eleman ihtiyacını ortaya çıkarmıştır. Üniversiteler hem bu kalifiye elemanı yetiştirme hem de bu bilgiyi kullanıp işlenmesi açısından eğitim sisteminin vazgeçilmez unsurudur ve stratejik öneme sahip kurumların da en önde gelenidir. Üniversitelerin bu misyon dahilinde çalışabilmesi için ise en başta iyi bir strateji ve bu stratejinin de etkin bir şekilde uygulanması gerekmektedir. Bu çalışmada, iş dünyasındaki yönetim ve uygulama sorunlarının çözümünü ilgilendiren üniversiteler ile iş birliği ve stratejik yönetim ve stratejik planlamanın önemi genel olarak ele alınıp değerlendirilmektedir.

\section{A B S T R A C T}

The aim of this study is to examine and examine the cooperation and strategic management between business world and universities. As a result of the developments in science and technology, the needs of companies and organizations are changing. This has revealed the need for professional and technical qualified personnel to keep up with these innovations. Universities are an indispensable element of the education system in terms of both raising these qualified staff and using and processing this information and are the most prominent institutions of strategic importance. In order for universities to work within this mission, a good strategy and this strategy should be implemented effectively. In this study, the importance of cooperation and strategic management and strategic planning with universities that deal with the management and implementation problems in the business world are discussed and evaluated.

\section{Giriş}

Teknolojik gelişmelere bağlı olarak dünyada ticaret tamamen açık pazar haline gelmiş ve değişim kavramı gelişmenin en temel unsuru olarak belirmiştir. Bu süreç içerisinde şirketlerin hayatta kalabilmeleri için gelişen günümüz modern iş dünyasının gelişimindeki temel düşünce; topluma en verimli, en yetkin ve en doğru şekilde sunulacak strateji ve modellerinin geliştirilmesi ve böylelikle beklenti ve hedeflere ulaşılması amaçlanmaktadır. $\mathrm{Bu}$ da globalleşen ve süratle değişen sektörde bu hılı değişime karşı iş dünyasının ayak uydurabilmeleri için uzun vadeli hedef ve vizyona sahip olmaları, bu uzun vadeli bakış açısı ile gerekli olan stratejik modellerin belirlenerek uygulanması sonucu erişilebilir. Belirli bir hedef ve stratejisi olmayan bir örgüt, geleceği öngöremeyen ve nereye ulaşmak istediğini bilmeyen bir örgüt olarak adlandırılmakta ve günlük sıradan çalışmalar doğrultusunda, doğru ve uyumlu bir hedef belirleyemez hale gelmektedir (Güçlü, 2003: 61-85). Bu bakımdan stratejinin önemini belirten şu söz önem arz etmektedir. "Strateji stratejik harekete rehberlik edecek planlarl, manevralarl, modelleri, pozisyonlart ve perspektifleri geliştirerek, bir örgüt için bir odak noktast, uyum ve ahenk ile amaç yaratmak için kullanılır" (Nut ve Backoff, 1992: 55).

\footnotetext{
* Sorumlu yazar/Corresponding author.

e-posta: mnaciefe@gmail.com
} 
Çağımızda hızla gelişme gösteren yönetişim ve teknoloji alanında olabildiğince artan rekabet ve büyük ölçekli şirketlerin öncülük ettiği küreselleşme faaliyetlerinin arttığı dünyamızda, şirketlerin klasik yöntemlerle hayatta kalması mümkün değildir. İşletmeler açısından ise hayatta kalabilmek için çevresini çok iyi analiz etmesi, işletmenin güçlü ve zayıf yönlerinin belirlenmesi, bunun yanı sıra dişsal faktörlerin etkilediği fursat ve tehditleri öngörerek yapacak olduğu faaliyetlerde bu analizleri uygun şekilde kullanmasıdır (Akdaş, 2015: 1-19). Tüm işletmelerin kendine has bir yapısı olduğu düşünülerek, işletmenin öncelikli amacı, vizyonu, misyonu ve politikasını oluşturması ve stratejisini de bu yönde oluşturup uygulamalıdır. Stratejik yönetimde tüm sistemler, özellikle denetim ve analiz sistemleri bilimsel metotlara göre uygulanmalıdır, aksi halde sistematik faaliyetlerden söz edilmesi pek mümkün değildir (Aktaş, 2015: 18).

Stratejik planlama değişen şart ve koşullarla birlikte bu değişimin uzağında kalmak istemeyen, faaliyet alanında söz sahibi olmak ve varlığını korumak isteyen kurumlar için önem arz eder hale gelmiştir. Bu durum neticesinde birçok sektörde olduğu gibi eğitim alanında da kendini göstermiştir. İletişim teknolojilerinin gelişmesi, eğitim sisteminin sorgulanmasını ve geliştirilmesini zorunlu kılmıştır. Bundan dolayı eğitim ortamları yeniden düzenlenmiş, artan kalifiye ara eleman eksikliği giderilmeye çalışılmıştır. Kurum içi yöneticileri stratejik planları hazırlarken eğitim sisteminin istediği amaçlar doğrultusunda planlı, etkin ve verimli bir şekilde uygulamaya çalışmışlardır (Gültekin \& Mazi, 2016: 450-453). Bu durumda entegrasyon sürecinin nasıl ve hangi şartlarda gerçekleşmesi gerektiği sorusuyla karşılaşılmaktadır. $\mathrm{Bu}$ süreci yönlendirecek ve hız kazandıracak faktörlerden birisi ya da belki de en kritiği "stratejik planlama ve stratejik yönetim" kavramıdır. Üniversite kurumları böylece küresel bazda gerçekleşen değişimlere adapte olarak karşılaştığı sorunları daha kolay tespit ederek çevreyi bu değişime hazır hale getirebilir (Gültekin \& Mazi, 2016: 454-464). Bu entegrasyon sisteminin belirlenen hedeflere ulaşabilmesini sağlayacak en önemli etken ise insan kaynağıdır. Bu insan kaynağının donanımlı yetişmesi ile belirlenen hedeflere ulaşma arasında doğrusal bir ilişki bulunmaktadır. Bundan dolayı nitelikli insan kaynağı yetiştiren gelişmiş ülkeler toplumsal, ekonomik ve teknolojik yönden ele alındığı zaman geri kalan ülkelere göre daha fazla gelişim gösterdiği görülmektedir. Beklediği gelişim düzeyine ulaşmak isteyen ülkelerin sanayi, ticaret ve hizmet sektöründe ihtiyacı hissedilen donanımlı insan gücünün eğitilmesi ve yetiştirilmesi ile bu eğitimi veren üniversitelerin yetkinliği çok büyük önem arz etmektedir (Şener, 2009:1).

Biz bu çalışmada gelişen üniversite-iş dünyası iş birliği faaliyetleri ve bu faaliyetlere stratejik yönetimin SWOT analiz yöntemiyle güçlü-zayıf yönleri, firsat ve tehdit ihtimalleri baz alınarak bu yönetim argümanlarından faydalanarak açıklanmaya çalışıllmıştır.

\section{Bulgular}

\subsection{Strateji}

Strateji kavramı uzun yıllar askeri bir terim olarak kullanılmıștır. Strateji; bir toplumun veya uluslararası toplulukların, savaş ve barışta benimsedikleri politikalara destek verme amacıyla ekonomik, psikolojik, politik ve askeri güçleri hep birlikte kullanma sanatı ve bilimi manasını içermektedir (Aktaş, 2015: 1-2) Strateji kavramı ile ilgili literatürde belli başlı bir tanım bulunmamakla birlikte birçok farklı tanım bulunmaktadır. Bu tanımlardan bazıları aşağıda örnek olarak verilmektedir;

"Strateji, bir organizasyonun uzun vadeli yönü ve kapsamı olup değişen bir ortamda paydaş beklentilerini yerine getirmek amacıyla kaynak ve yeterliliklerin yapılandırılarak avantaj elde edilmesinin yoludur" (Johnson, 2008: 3).

"Stratejinin özü faaliyetlerdir: faaliyetleri farkl şekilde yapmak ya da rakiplerinden farkl faaliyetler yapmak önemlidir. Aksi takdirde strateji rekabete karşı koyamayan herhangi bir pazarlama sloganından başka bir şey değildir" (Porter, 1996: 61-78).

"Strateji, yöneticilerin şirket performansını arttırmak için kullandiğ bir dizi ilgili eylem setidir. Hepsi olmasa bile rakiplerine göre üstün performansa ulaşan şirketlerin çoğu için nihai bir mücadele, meydan okumadır" (Hill, Jones, ve Schilling, 2013: 3). "Strateji, belli bir hedefe ulaşmak için kaynakların dă̆llımını planlamakla ilgilidir" (Kotler vd., 2010: 6).

Tüm bu tanımlardan hareketle belli başlı bir strateji tanımı yapacak olursak strateji; Bir organizasyonun belirlenen hedeflere ulaşması amacı ile uzun vadede ve yeniliklerle beraber değişen çevrede belirlenen faaliyetleri, rakiplerine göre farklı yapması ya da rakiplerine kıyasla farklı faaliyetler yapması, tüm bunları organizasyonun kendi içindeki kaynaklar ve yetenekleri çerçevesinde tasarlayarak rakiplerine karşı üstün rekabet ve performans avantaj1 sağlaması denilebilir (Çiftçi, 2018: 7).

\subsection{Yönetim}

Literatür taramaları sonucunda yönetim kavramının bilimsel açıdan MÖ 3000'lerde Sümerler ile başladığı düşünülmektedir. Sanatların en eskisi, bilimlerin en yenisi olarak tanımlanan yönetim kavramını açıklayan birçok ifade bulunmaktadır. Bu tanımlardan en belirgin olanları şu şekilde aktarmak mümkündür (Aktaş, 2015: 4)

Taylor bu kavramın tanımını; "Yönetim ne yapmak istediğini bilme ve en kaliteli işi en ucuza yaptırma sanatıdır" diye ifade ederken Fayol ise "Yönetim öngörmek, planlamak, organize etmek, eşgüdüm ve kontrol etmek" olarak açıklamaktadır. Yönetim bilimcilerinin fikir birliği yaptığı tanım ise "yönetim, başkaları vasıtasıyla iş görmektir" şeklinde tanımlanmaktadır (Can \& İbicioğlu, 2008: 253-275).

Yönetim evrensel bir kavramdır. Önceden nasıl davranacağının ve ne yapacağının tahmin edilmesi oldukça güç olan insanla uğraşır. İnsanın toplumla iç içe yaşama gereği diğer bireylerle ilişkilerini, bireylerin çeşitli etkenler sonucundaki davranışlarını ele alır. Bu anlamda her birimiz birer yönetici konumundayızdır. Zamanımızı, ustalığımızı ve davranışlarımızı planlar, örgütler, hal ve hareketlerimizi kontrol eder ve yönlendiririz (Can, 2001: 1-19). Yönetim en küçüğünden (işletme, aile vb.) en gelişmişine (devlet, uluslararası örgütler vb.) kadar bütün örgütlerde önem arz eden ve doğru uygulanması gereken bir işlevdir. Yönetim, organizasyonların hedeflerine verimli ve etkin ulaşabilmeleri adına olması gereken bir işlevdir (Tortop, 
İsbir, \& Aykaç, 1993). Örgütler için olmazsa olmaz bir öneme sahip olan yönetim, bir toplumun örgüt yapısındaki yönetim anlayışı ve uygulamaları ile o toplumun gelişmişlik düzeyiyle doğrusal anlamda bir bağ Yönetimin kalitesi bütün toplumu etkiler (Güçlü, 2003: 63). Yönetim, insan ve diğer kaynakları birleştirerek örgütsel amaçlara verimli ve etkin bir işleyişle mümkün olan en iyi şekilde ulaşma sürecidir. Başka bir deyişle yönetim: sermaye, teknik donanım, iş gücü vb. gibi örgütsel kaynakların, organizasyonun amaçlarını gerçekleştirmek için etkin bir biçimde koordine edilmesidir (Rachman vd., 1993: 154).

Yönetimin ortaya konması ve bir bilim olarak ele alınmaya başlanması şu evrelerden sonra olmuştur. Taylor'un "bilimsel yönetim" kuramı 20. Yüzyılın başında başlayarak İkinci Dünya Savaşına kadar olan dönem çerçevesinde, işletmelerin kendi içine dönük rasyonellik arayışları söz konusu olmuştur. Önceliğin mal ve hizmet beklentililerinin karşılanması olarak belirlendiği, 1950'li tarihlere kadar en öncelikli araştırma konusu, mekanistik kalite kontrol çabalarıdır. $\mathrm{Bu}$ dönemdeki amaç, sürümden kazanarak olabildiğince ucuza çok miktarda üretmektir. Fransız yönetim bilimci Fayol'un 1916 yılında yayınlanan "sınai ve umumi işlerde idare" adlı eserinde yönetim literatürüne kazandırdığı beş fonksiyonel aşamalı yönetim süreci (POYED) ve on dört yönetim ilkesi, 20. Yüzyılın ortasına kadar genel kabul gören bir kuram olmuştur. İkindi dünya savaşının bitmesiyle başlayan ve 1960'lı yıllara kadar devam eden süreçte, yönetim biliminin gelişiminde önemli hareketlenmeler olmuş, rekabetin korkutucu şekilde artmaya başlaması, Batılı işletmeleri arz ekonomisinden, müşterinin isteklerinin öneminin dikkate alındığ 1 bir talep ekonomisine geçişi başlatmıştır.

1960 ile 1970 yılları arasında pazarlama anlayışı değişmiştir. $\mathrm{Bu}$ dönemde tüketim toplumu oluşarak yönetsel yaklaşımlarda büyük değişimlerin yaşandığı bir dönüm noktası olmuştur. $\mathrm{Bu}$ dönemde, işletmeler, başlıca ticari fonksiyonlarını geliştirme çabasına girmişlerdir. $\mathrm{Bu}$ yeniliklerin en önemlisi satış yöntemlerini çeşitlendirerek anket ve kamuoyu yoklamaları ile pazar araştırmalarının yapılmasıdır.

İşletme yöntemi stratejisinin ön plana çıkması 1970'li yıllara rastlamaktadır. $\mathrm{Bu}$ dönemde pazar rekabetinin yoğunlaştığ zamanladır. Giderek artan rekabet baskısı, işletmelere yatırım ve pazarlama konusunda stratejik hedefler belirlemesini mecburi kılmıştır. Stratejik yönetim yaklaşımı, işletmelere ticari fonksiyonlarının rolünü güçlendirerek ArGe çalışması gibi geliştirici yönde ürün ve yöntem bazında ki faaliyetlere yönlendirmiştir. 1980'li yıllar, işletme yönetimleri bakımından 1970'lerden itibaren baş gösteren ve giderek sıklaşan üç hayati faktörü artık veri olarak kabul etmeye başladıkları dönem olarak görülmektedir (Düren, 2000: 11).

1. Hammadde ve enerji konusundaki sınırlılık ve artan baskilar,

2. Finans ve para piyasalarındaki sürekli dalgalanmalar,

3. Yeni ekonomik dünya düzenine geçiş:

Bu bağlamda 1980'li yıllardaki yenilikler, işletmeleri, insan kaynaklarını daha verimli kullanımına yönlendirmiştir. $\mathrm{Bu}$ amaçla, Japon yönetim modelleri de örnek alınmış ve yönetimde katılımcı anlayışının benimsenmesi çabaları yoğunluk kazanmıștır. 1980'li yıllarda örgütlerde çalışanların hedefleri ile örgütün amaçları arasında bütünleşme sağlanmaya başlanılmıştır (Güçlü, 2003: 66).

\subsection{Stratejik Yönetim}

Stratejik yönetim kavramı TDK sözlüğünde "Ulaşmak istenilen sonuç, maksat" olarak tanımlanmaktadır. Stratejik yönetim işletmelerin gelecekte ulaşmak istediği hedefi ve amacını ifade eder. Bu hedefler işletmelerin stratejilerinin temelini oluşturur. Çünkü Amaçlanan hedeflerin gelecekte bulunulmak istenen duruma göre düzenlenmesini teşkil etmektedir (Aktaş, 2015: 4).

Stratejik yönetimin hedefi, işletmelerin artarak devam eden çevresel koşullara adapte olmasını sağlamaktır. Bu sebeple, işletmeleri çevresel değişkenlerle iç içe düşünmek ve yönetsel kararları olası çevresel değişimleri göz önüne alarak vermektir. Stratejik yönetimde asıl amaçlanan geçmişteki başarıları yinelemek değil, beklenmeyen durumlarla mücadele etmek ve başa çıkarak, olası çevresel problemleri halletmektir. $\mathrm{Bu}$ problemleri çözme adına geliştirilmesi gereken stratejiler; yöneticilerin öngörülerinden ve denemeyanılmaya bağlı yaklaşımlarından problemin kapsadığı değişkenlerin titizlikle ve sistemli analizine kadar pek çok farklı yaklaşım kullanılabilir. $\mathrm{Bu}$ nedenle, strateji geliştirilirken birçok modelle karşılaşılabilir. Ama burada geliştirilen stratejilerin hangi model kullanılırsa kullanılsın, bu koşullara en uygun stratejinin uygulanması gerektiği önemle vurgulanmaktadır. Çünkü stratejik yönetim bu şekilde başarıya ulaşacaktır (Güçlü, 2003: 61-85).

Genel anlamıyla strateji, işletmeye yön vermek ve rekabet üstünlüğü sağlama amacıyla, işletme iç ve diş çevresini daima analiz etme, amaç ve hedefleri belirleme, bu amaç ve hedeflere ulaştıracak yöntemleri planlama ve kaynakları oluşturma bilgi ve becerisidir (Gültekin ve Fikret, 2016: 450453).

Çağımızda çevre sosyal, teknolojik ve ekonomik gelişmelere bağlı olarak sürekli halde ve hızlı bir biçimde değişmekte, bu değişime ayak uydurma ise git gide zorlaşmaktadır. Değişime ayak uydurmak ve bu değişimlerin organizasyonlara yönelik ne şekilde etkilerinin olacağını öngörmek organizasyonlar açısından hayati öneme sahiptir. Stratejik yönetim sayesinde bu etkileri öncesinden öngörerek organizasyonların gelecekleri şekillendirilip yön verilebilmektedir (Nurefşan, 2017: 4).

Stratejik planlama yapılırken iç ve diş çevre analizleri kullanılması gerekmektedir. Çünkü devamlı gelişen dünya şartlarında şirketlerin sürdürülebilirliğinin sağlanması gerekmektedir. Benimsenen stratejiyi hayata uygun bir şekilde geçirmek de doğru stratejiyi tanımlamak kadar önemlidir. Stratejik yönetim, sistematik, mantıklı ve rasyoneldir. Uygun stratejinin hayata geçirilebilmesi için gerekli hazırlık çalışmaları ve tedbirler gereklidir. Stratejik yönetim, ulaşılmak istenen hedefin belirlenmesi ve bu aşamada eylemlerin yönlendirilmesi harekete geçirilmesini sağlar. Etkin bir yönetim şekli olması için bireysel ya da birimlerin yaptığı çalışmalar birbirleriyle ilişkileri kurulmalı ve ortak amaçlara yönlendirilmelidir. Bundan dolayı yöneticilerin ve çalışanların eylemlerini ve kararlarını uyumlaştırıp kurumsal bir oyun planı oluşturulması adına stratejik yönetim oldukça önemlidir (Çarıkçı, 2014: 24). 


\subsection{Stratejik Yönetimin Önemi}

Öncelikle işletmenin seviyesi strateji; özel mal ve hizmetleri barındıran pazarlarda rekabet içerisinde oldukları ana rakiplerini kendi faydaları doğrultusunda yönlendirerek rekabet avantajı kazanma adına belli faaliyetler dizisinin ve uygulamaların bir araya getirilmesi ve koordine edilmesidir. Buradaki asıl amaç işletme ile rakip işletmeler arasında değişkenlik ortaya koymaktır.

Stratejik rekabet, işletme paydaşlarını ve müşteri topluluğunu, özgün rekabetçi üretim pazarı aslında, kalite, fiyat ve inovasyon gibi rekabet üstünlüğünü kullanarak tatmin sağladığında anca karşılık bulacaktır (Aktaş, 2015: 119)

Stratejik yönetimin diğer bir evresini oluşturan rasyonel analiz, İşletmenin iç ve diş çevre analizinin (SWOT analizi) yapılmasıdır. İşletmelerin faaliyet gösterdikleri sektörde başarılı olabilmeleri adına önemli noktalarda güçlü olmaları ya da ihtiyacını hissettikleri güce en hızlı şekilde ulaşmaları gerekmektedir. Buna ulaşabilmek için ise öncelikle iç ve diş çevre şartlarının ve rekabet halindeki firmaların durumu göz önüne alınarak üzerinde yoğunlaşılması gereken noktaların belirlenmesi gerekmektedir. Daha sonra ise bu belirlenen noktalara uyumlu olarak uyarlanıp, geliştirilen stratejilerin sürekli kontrolü sağlanarak, organizasyon üyelerinin yaratıcılıklarını ortaya koymalarını sağlayacak şekilde çağın şart ve gereklerine göre revize edilmesi gerekmektedir (Karbuzoğlu, 2014: 1).

Stratejik yönetimde misyon, görev ve kurum felsefesi olarak iki farklı anlamda kullanılmaktadır (Güçlü, 2003: 6185). Misyon, bir şirketin amacını ve varoluş nedenini net bir şekilde ortaya ifade eden bir kelimedir (Nut ve Backoff, 1992: 55). Ama insanın istediği noktaya gelmek için tek başına amaç yeterli değildir. Net bir amaç ne yapışacağını açıklar; ama amaca nasıl ulaşılacağını yöntemini göstermez. $\mathrm{Bu}$ sebeple sahip olunan temel değerlerin açıkça ortaya konulmalı ve hayata geçirilmesi şarttır (Dinçer, 1998: 3637).

Vizyon kısaca, stratejik amaçları asıl işlerini yürürlüğe koymayı amaç eder, ümit ve hayal edilen geleceğin önemli sonuçlarıyla ilgilenir yoksa süreci ya da onların nasıl başarılacağının araçlarıyla ilgilenmez (Beril, 2011: 65). Vizyon, planlanan hedefleri hayata geçirmek için mevcut durumun analizini yapar ve bu şekilde oluşturulan, ana değerler ve uzun vadeli stratejileri kapsar (Papatya, 1998: 23-24). Vizyon, ortak bir amaca ulaşmak için örgüt çalışanlarını hedefe kenetlemektedir. Bugünden geleceği daha net gören işletmeler, rakiplerine göre daha avantajlı olacaklardır (Muslu, 2014: 42).

Stratejik yönetimin sahip olduğu özellikler kısaca şu şekilde siralanabilir:

(i) Kurum içi analiz yaparak, kurumun içsel koşullarını ve yeteneklerini belirlemek,

(ii) Dış çevre analizi yaparak, kurumun paydaşlarını sisteme dahil etme,

(iii) Kurumun yapabilirliklerini tespit etmek için diş çevrenin fikirlerini, durumunu iç çerçevesiyle karşılaştırmak,

(iv) Kurum misyonu oluşturarak, kurumun hedeflerini, amaçlarını, felsefesini aktarmak,

(v) Kurumun hedeflediği vizyona ulaşmayı planlamak, (vi) Kurum içi farklılaşmayı önleyerek koordinasyonu sağlamak,

(vii) Kurumların belirledikleri hedeflere ulaşmak için gerekli stratejileri belirlemek,

(viii) Belirlenen hedeflere ulaşmak için gerekli stratejiler çerçevesinde her yıl hedefler geliştirmek,

(ix) Belirlenen stratejilerin kurumun üst yönetimi, alt yönetimi ve diğer personel tarafindan benimsenmesi,

(x) Stratejik yönetim, işletmenin ana hedeflerinin uygulanabilmesi için lazım olan kaynakların verimli bir şekilde dağıtılmasıyla ilgilenmektedir,

(xi) Stratejik yönetimi, teknolojik altyap1, görev, kurumun personel kaynağı ve kurumun diğer kaynaklarıyla bağdaştırılarak bütçelenmiş kaynaklarla uygulamak,

(xii) Başarı ölçümü yapılarak gelecekte alınacak kararlarda etkili olmak (Dinçer, 1998: 30-45).

\section{3. İș Dünyası ve Üniversiteler}

Ortaçağda ilk üniversiteler ortaya çıkmaya başlamıştır. Bu süreçten 19. Yüzyıla kadar üniversitelerin temel görevi eğitim olmuştur. Üniversiteler toplumsal ve tarihsel perspektifte bilgi üretiminde hayati bir rol oynamaktadır. Üniversiteler üretilen bu bilginin topluma yayılmasında önemli bir rol üstlenmiştir. Sanayi devriminin başlamasıyla birinci akademik devrim olarak adlandırılan eğitimin yanı sıra araştırma çalışmaları da üniversitenin temel görevlerinden birisi olmuştur. Sanayi odaklı ve uygulamalı araştırmalar ise ikinci akademik devrim olarak adlandırılır. $\mathrm{Bu}$ dönemde üniversite-sanayi iş birliğinden bahsedilmeye başlanmıştır. İlk üniversite-sanayi iş birliği Amerika Birleşik Devletlerinde ortaya çıkmıştır. Bundan dolayı ABD'nin bugünkü gelişmişliğinde önemli bir payı olduğunu söyleyebiliriz (Kiper, 2010: 19).

İş dünyası ile üniversiteler arasında iş birliğinin sağlanması, üretim ile bilim arasında bağın kurulması elzemdir. İş dünyasıyla bağlantısı olmayan bir üniversitede eğitim gören öğrencilerin okul hayatı bittikten sonra iş hayatının şartlarından haberdar olamaz. İş dünyasından kopuk bir üniversitenin kendisini geliştirememesi dünya şartlarında rekabetten geri kalmasına neden olacaktır. Bu sebeple, Üniversiteler ile iş dünyasının bağlantılarının kurulması ve buna dair mekanizmaların üretilmesi günümüz dünyasında şarttır (Korkmaz, 2015: 7-11).

Üniversiteler, bulundukları çevresindeki üretim dünyasıyla iç içe geçemezlerse, eğitim kurumlarında yetişen gençlerin yeni teknoloji ve üretim tekniklerinden takip etmeden mezun olmalarına, eğitmenlerin de kendilerini geliştirecek projeler üretmede yetersiz kalmasına neden olacaktır. Başka bir deyişle bu iş birliği her iki tarafta içinde hayati öneme sahiptir. Ancak bu öneme karşın iki taraf arasında iş birliği oldukça yetersizdir. Birçok büyük imkânlara ve dinamik bir kadroya sahip üniversite bir adım ötede dururken, işletmeler bu imkânlardan yararlanmamaktadır. Bu sebeple, iş dünyası üniversite iş birliği sağlayacak, iş dünyası ile üniversiteyi kapsayacak, sürdürülebilir iş birliği mekanizmalara ihtiyaç duyulmaktadır (Korkmaz, 2015: 7-11).

Üniversitelerde yapılan araştırmalar neticesinde elde edilen bilgilerin, uygulama safhasına geçilmesinde Stratejik Yönetim'in İlkeleri her iki tarafa da büyük faydalar sağlayan çalışma olarak çeşitli ülkeler tarafindan ele alınmakta ve 
kullanılmaktadır. Ülkemizde Ar-Ge’ye ayrılan finansal kaynaklar çok sınırlı olduğu baz alındığında, üniversitelerde elde edilen bilginin etkin şekilde kullanılması, hali hazırdaki kaynakların rasyonel bir şekilde iş dünyasına entegre edilerek kullanılması bakımından iş birliği büyük önem taşımaktadır (Şenol, 2009: 94-111).

Stratejik Yönetim değer zincirinde bilgiyi ele alma ve üretme ile bilgiyi işleme ve entegre etme adına iki önemli aktör öne çıkmaktadır. Bu aktörler, ulusal ekonomi sisteminin ana bileşenleridir bir anlamda. Bunlar; Bilgi üretimi ve eğitim alanını temsil eden araştırma kurumları ve üniversiteler ile teknoloji ve üretimi temsil eden büyük işletmeler ve KOBİlerden oluşan endüstri sistemleridir yani genel anlamıyla iş dünyasıdır. Ulusal inovasyon sistemlerinin temelinde bulunan bu iki asıl aktör, son zamanlardaki ilerlemelere bağlı olarak hem kendi aralarında hem de diğer değişkenlerle ilişki ve ortak çalışmalarında kökten değişimler geçirmişler ve beklenen fonksiyonlara ayak uydurabilenlerin şansı oldukça yükselmiştir. Özellikle, amaç ve istekleri birbirinden tamamen farklı üniversite ile şirketler arasındaki ilişski ve iş birliğiyle ortaya konan başarılar ulusların gelişmişlik düzeylerinde de fazlasıyla etkili olmaya başlamışlardır (Kiper, 2010: 18-19).

Girişimci ve endüstriyi besleyen üniversitenin kilit özellikleri aşağıdaki gibidir;

(i) Kampüste öğrenim gören bütün üniversite personelinin girişimci kapasitesini geliştiren güçlü liderlik

(ii) Üniversite-sanayi iş birliğini artıran, katma değer doğuran dış paydaşlarla güçlü bağlar kurmak,

(iii) Kurumlar ve bireyler üzerinde etki bırakan girişimci sonuçlar doğurmak,

(iv) Yenilikçi öğrenme tekniklerini uygulamak,

(v) Kurumlar arası etkili bilgi akışını sağlamak,

(vi) Liderlik uygulamalarına ve girişimci düşünmeye teşvik edici olmak (Sakınç \& Bursalığlu, 2012: 9299).

\section{1. Üniversite-İş Dünyası Bağlantılarını Güçlendiren Çalışmalar}

\subsection{1. Üniversite-Sanayi İş Birliğiyle Yürütülen Devlet Destekli Araştırma Projeleri}

İş dünyası ve üniversitelerin birlikte yürüttükleri özel araştırma projelerinin üzerindeki rekabet ve finansal baskıları azaltmak üzere, birçok hükümet mali destek programları yürütmektedir. Devlet destekli araştırma projeleri, rekabet öncesi alanlarda ama uygulamaya dönük çalışmalar için kullanılmaktadır. Buna benzer desteklerle, genellikle üniversite-iş dünyası ilişkisini ve ă̆ yapısını geliştirmek; araştırmanın ticarileşme hızını arttırmak ve teknoloji transferini yapmak, İş dünyasının araştırmaya daha çok kaynak aktarmasını sağlamak; üniversite araştırma programlarını iş dünyası ve Pazar ihtiyaçlarına yöneltmek; küçük firmaların araştırma kapasitesini geliştirmek gibi pek çok amaç birlikte sağlanmaya çalışılır.

\subsubsection{Teknoparklar}

Teknoparkların temel girdisi yaratıcılıktır ve yaratıcılık teknolojilerin araştırılıp, geliştirilmesi için en temel etkendir.
Yaratıcılığın bilgi alışverişine odaklanmış hali; bire bir temaslar, medya hizmetleri veya elektronik bilgi alışverişine göre daha etkindir. Bu işleyiş hali araştırmacıların birbirleri ile daha kolay iletişim kurabilecekleri çeşitli mekân ve firsatların ortaya konmasını hızlandırmıştır. $\mathrm{Bu}$ açıdan bakıldığında teknoparklar Bilgi Toplumunun, Sanayi ve Üniversite iş birliklerinin bir simgesi olarak ortaya konmuştur. Çünkü teknoparklar birbirinden farklı bilim alanlarını veya benzer bilim dallarını tek bir çatı altında birleştirerek bir sinerji ortaya koymaktadır. Teknolojiye, bilgiye ve sosyal hayattaki değişimlere bağlı olarak yaşanan bu gelişmeler hem bireysel açıdan hem de firmalar bazında hem de devlet politikalarında ucuz ve katma değeri yüksek olan teknolojilere ihtiyaçları arttırmıştır. $\mathrm{Bu}$ talepler ise doğal olarak teknolojiyi ele alıp üretecek merkezler olan teknoparkları kaçınılmaz hale getirmiştir (Uzun, 2011: 90).

\subsection{3. Üniversite-Sanayi Ortak Araştırma Merkezleri}

Üniversite- İş dünyası iş birliği yöntemlerinde genellikle bir taraf daha ağır basar ve yönlendirici olduğu çalışma sistemleri görülmektedir. Mesela üniversite araştırmasına sanayi katk1 verir veya sanayi tarafından sanayi tarafindan sipariş verilen bir çalışma üniversite bünyesinde çalışır. Her iki kesimin de etkin olarak yer aldığ 1 , gerçekten verimli iş birliği süreçlerinin yaşandığı, uzun vadeli ve ilgili bütün tarafların karşılıklı menfaatleri gözeten bir iş birliği modeli ABD'de (I/UCRC) program adı altında tasarlanarak oldukça verimli sonuçlar alınmıştır. Bunun üzerine birçok ülke de benzer yaklaşımları kendi programlarını oluşturarak ve uygulamaya konmuştur. Buna benzer programlar genellikle Ulusal Bilim Kurumu (NSF) kökenli programlar olarak anılmıştır. Türkiye'de ise 1996-2006 yılları arasında TÜBİTAK'ın yürüttüğü ÜSAMP bu bağlamda bir program olarak tarihteki yerini almıştır (Kiper, 2010: 59).

\subsubsection{Stratejik Yönetim Uygulamalarının İş Dünyası Açısından Önemi}

Günümüz dünyasında birçok ülkelerin ana hedefi ürettikleri mal ve hizmet anlayışında kaliteyi, yüksek verimliliği ve hakkaniyeti ön plana çıkarmaktır. Bunu gerçekleştirebilmek için yeni yöntemler geliştirerek benimsenmesi gerekmektedir. Öncelikle üniversitelerin geliştirdiği yöntem ve teoriler özel sektör yöneticileri tarafından uygulanmaya çalışılmaktadır. Bunların başında ve belki de en önemlisi stratejik yönetim anlayışı gelmektedir. $\mathrm{Bu}$ anlayış ile özel sektör organizasyonları uzun vadeli stratejiler geliştirerek vizyon oluşturmayı amaçlamaktadır. Stratejik yöntemin konusunu hedefleri başarmak için ne yapılması gerektiğini ve bu planların en etkili nasıl uygulanacağını belirlemektir. Belirli bir stratejisi olmayan organizasyonlar ya da uygun stratejiyi belirlemeyen örgütler kendilerinden emin olamayacaklardır. Çünkü bir örgütün geleceği daha önceden belirlenmiş ve belirsizlik içinde bulunmaktadır. Böylesi bir durumda başarısızlık kaçınılmaz son olacaktır. Uygun bir stratejisi olmayan örgütler kaynaklarını verimli ve etkin kullanamazlar. Bundan dolayı mali kaynaklar uygun bir şekilde kullanılamayacaktır (Güçlü, 2003: 61-85).

Gelişmekte olan ülkeler, sürekli değişkenlik gösteren politik, ekonomik ve sosyal değişiklikler karşısında ayakta kalabilme adına, yaşanan istikrarsızlık ve belirsizliklerden en az etkilenmek için stratejik bir bakış açısı ve buna dair bir hareket mekanizması belirlemek ihtiyacı hissetmiştir. Bu 
açıklama çerçevesinde stratejik yönetim uygulaması organizasyonların çevre ile şirket amaçları arasındaki ilişkilerini ortaya koyup farklı yapısal değişikliklerin önünü açarak bu şirketlere önemli firsat ve faydalar sağlamaktadır. Gelişmekte olan ülkeler arasında yer alan ülkemizde ve amacı kar elde etmek olsun veya olmasın ülkemizdeki firmalarda stratejik planlama ve stratejik yönetim süreçlerinin önemine bakmak gerekir ise;

(i) Her şeyden önemlisi stratejik yönetimi ilerlemenin basit yolu olarak görmemek gerekir; ancak zaman içerisinde ilerlemeyi kolaylaştıran bir etkisi vardır. Çünkü ortak bir bakış açısını yansıtır. Vizyonu barındıran hatta gerçekçi olmasıyla birlikte hedeflenebilir ve başarılabilir bir geleceği ele alır.

(ii) Giderek karmaşıklaşan ve dinamik hale gelen iş dünyasında taşları yerine koyma ve öngörülü değişim için bir yol haritası olma özelliğini barındırır.

(iii) Geleceğe yönelik olarak belirlenen günlük kararları etkilemesi ve vurgu yapması nedeniyle şirketin geleceğindeki faaliyetlerini de kapsamaktadır.

(iv) Stratejik Yönetim uzun süreli bir bakış açısı taşısa de, şirketlerin stratejik amaçlarına ulaşmalarına dair güncelleme ve yaklaşımları barındırması nedeniyle esnek ve uyumlu bir özelliği barındırır (UÜ, 2002).

Stratejik yönetimin amacı, şirketlerin gelecekteki performanslarının arttırılması, kârlılık ve verimliliklerinin yükseltilmesidir. Stratejik yönetim geleceğe dair bir vizyon belirlemeyi amaçlamaktadır (Aktaş, 2015: 1-19). Stratejik durumları algılayan ve analiz etmeye çalışan organizasyonel süreç ve prosedürlerin bir bütünüdür. Bu bütünsel model, organizasyonların öğrenme ve adaptasyon algılamalarına katkıda bulunmaktadır. Adaptasyon ise organizasyonların ve firmaların çevreleriyle daha sağlıklı bir ilişki ve bir bütünlük kurmalarını belirtmektedir (Koçel, 2003: 15-19). Bu açıdan bakıldığında stratejik yönetimin, şirketlerin başarılı olmaları ve yaşamsal faaliyetlerini uzunca bir süre devam ettirebilmeleri adına çok önemli bir etkiye sahip olduğu kabul edilmektedir.

\section{Sonuç}

Üniversite ve eğitim kurumların başlıca görevi, değişime hazırlıklı olmak hatta bu değişimi yönetmektir. Gerçekleşen bu değişim veya genişleme kaçınılmaz olarak kimi problemleri de beraberinde getirecektir. Stratejik yönetim, genel itibariyle gelecekteki muhtemel yeniliklere ve değişime şimdiden hazırlıklı olmayı öngörmektedir. Üniversitelerin, kurum kültürüne dayanan stratejik plan çalışmaları yapmalarının, kurumun maksimum kalitede düzeyinin sağlanmasında etkili olacağı öngörür (Gültekin ve Fikret, 2016: 450-453).

İş dünyası ile üniversiteyi bir araya getirecek mekanizmaları üretmek ve bu mekanizmaları devamlı hale getirmek için iş birliği mekanizmaları kısmen de olsa kurumsal olarak yerine getirilmeye çalışılmaktadır. Başlıca TEKNOKENT ve KOSGEB gibi projelerle akademisyenlerden danışman, değerlendirici veya bireysel şirketler kurmaları için teşvik edilmektedir. Ama bu olması gereken düzeyin çok altındadır. $\mathrm{Bu}$ konuda neler yapılabileceğine göz atarsak;

(i) Üniversitelerin potansiyeli ve imkânları ile iş dünyasının ihtiyaçlarını tespit ederek mevcut durumun analizi yapılmalı, (ii) Bölgenin stratejik ilerleme planı çıkarılmalı, önemli sektörler tespit edilmelidir. Üniversite iş dünyası iş birliğinin yönü tayin edecek bilimsel ve uygulama ayaklarının beraber işlendiği bir yöntemle üniversite iş dünyası iş birliği çalıştayı düzenlenmelidir.

(iii) Bölge için önemli bir başlangıç olması için çıkarılan sonuçlara göre iş birliği modelleri oluşturulmalı, gelişmeleri içeren uygun bir çalışma yapılmalı,

(iv) Hazırlanan stratejik plana göre, üniversitenin iş dünyasına yönelik birimleri (İktisadi ve İdari Bilimler, Mühendislik, Veterinerlik vb.) harekete geçirilmeli (Korkmaz, 2015: 7-11).

Planlama ve analiz safhası stratejik yönetimin en önemli aşaması olduğunu söyleyebiliriz. Yapılan iyi bir plan ve analiz süreci organizasyonların belirsizliklerini ortadan kaldırarak elimine ederek avantaja çevirecektir. Stratejik planlamada faaliyet süreçlerini belli aralıklarda kontrol ve değerlendirme yaparak, elde edeceği verileri feedback yaparak ve gelişmelere bağlı olarak, strateji revizyonu yapmalıdır. İşletmelerin stratejinin oluşturulmasında ve stratejik yönetimin belirli aşamalarda bulundurulmasının faydalı olabilecek hususlarına kısaca değinirsek.

(i) Stratejiler anlaşılır olmalı ve somutlaştırılmalı,

(ii) Tahminler değil varsayımlar tartışılmalı,

(iii) Titiz bir iş ve iletişim perspektifi kullanılmalıdır,

(iv) Kullanılacak kaynakların imkânları ve dağıtımın planlaması daha önceden planlanmalıdır,

(v) İşletmenin stratejileri açıkça tespit edilmelidir,

(vi) Çalışanların performansları devamlı izlenmelidir,

(vii) Herkesin yeteneğine göre iş dağılımı yapılmalı,

(viii) Başarılar uygun bir şekilde ödüllendirilmelidir (Aktaş, 2015: 1-18).

Üniversitelerin kalkınmadaki girişimci rollerini engeller arasında fon teminindeki güçlükler, kurumsal yönetişimin zayıflıkları, üniversite-iş dünyası arasındaki ilişkilerde etkin ve güçlü bağların yaratılamaması ve kurumsal stratejilerdeki yetersizlikler sayılabilir. Üniversite-iş dünyası-devlet sarmalında bireysel ve kurumsal kapasitenin artırılması ve etkileşimin sağlanması suretiyle, üniversitelerin girişimciliğe ait politikaların verimliliği ve sürdürülebilirliği bakımından kendi bölgelerinde daha önemli rol oynamaları mümkündür (Okay, 2009: 94-111). 


\section{Kaynakça}

Aktaş, K. (2015). Uluslararası İşletmelerde Stratejik Yönetim, İstanbul. Uluslararass Yönetim ve Sosyal Araştırmalar Dergisi, 2(1).

Bilgen, B. (2011). Kurumsallaşma Üzerine Bir Karar Destek Sistemi Oluşturulması-Türk Inşaat Sektöründe Örnek Uygulama (Kural Tabanlı KDS Modeli). Yüksek Lisans Tezi. İstanbul: İstanbul Teknik Üniversitesi

Can, A., \& İbicioğlu, H. (2008). Yönetim ve Yöneticilik Yönünden Üniversite Hastanelerinin Değerlendirilmesi. Süleyman Demirel Üniversitesi İktisadi ve İdari Bilimler Fakültesi Dergisi, 13(3).

Can, H. (2001). Yönetim Bilimli ve Tarihçesi, Yönetim ve Organizasyon. Ankara: Nobel Yayın Dağıtım.

Çarıkçı, G. N. B. (2014). 'Stratejik Yönetim', Uygulamalı Üretim Yönetimi El Kitabl. (Ed. O. Kulak-B. Durmuşoğlu). Kocaeli: TÜSSİDE.

Çiftçi, D. (2018). Yöneticilerin Stratejik Yönetim Anlayışlarının Referansta Bulunduğu Strateji Okullart: Nitel Bir İnceleme. Yüksek Lisans Tezi. Sakarya: Sakarya Üniversitesi.

Dinçer, Ö. (1998). Stratejik Yönetim ve Işsletme Politikası. İstanbul: Beta Yayınevi.

Düren, Z. (2000). 2000'li Yıllarda Yönetim. İstanbul: Alfa Yayınları.

Güçlü, N. (2003). Stratejik Yönetim. Ankara, G. Ü. Gazi Ĕ̈itim Fakültesi Dergisi, 23(2).

Gül, N. (2017). Stratejik Yönetim ve Kamu Çalışanları Açısından Stratejik Yönetim. Yüksek Lisans Tezi. İstanbul.

Gültekin, M. C., \& Mazi, F. (2016). Kırgızistan, Stratejik Planlama ve Stratejik Yönetim Uygulamalarının Meslek Yüksek Okulları Açısından Önemi. Akademik Başarı Dergisi, 55.

Hill, C. W. L., Jones, G. R., \& Schilling, M. A. (2013). Strategic Management: An Integrated Approach. Cebgage Learning.

Johnson, G., Scholes, K., \& Whittington, R. (2008). Exploring Corporate Strategy. London: Prentice Hall.

Karpuzoğlu, E. (2001). Aile Şirketlerinde Stratejik Planlama ve Aile Şirketlerine Özgü Planlar. Marmara Üniversitesi Işsletme Fakültesi, Öneri Dergisi.

Kiper, M. (2010). Dünyada ve Türkiye'de Üniversite-Sanayi Isşbirliği ve Bu Kapsamda Üniversite-Sanayi Ortak Araştırma Merkezleri Programı (ÜSAMP). Ankara: İşkur Maatbaacılık.

Koçel, T. (2003). Işsletme Yöneticiliği. İstanbul: Beta Basım Yayım Dağıtım A.Ş.

Korkmaz, A. (2015). İnovasyon ve Üniversite-İş Dünyası İşbirliği Üzerine. Ayrıntı Dergisi, 3(24), 7-11.

Kotler, P., Berger, R., \& Bickhoff, N. (2010). The Quintessence of Strategic Management What You Really Need to Know to Survive in Business. London: Springer.
Muslu, Ş. (2014). İşletmelerde Vizyon Ve Misyon Kavramlarının Kullanımında Oluşan Karmaşıklık; Türkiye'de İlk 100 Büyük Sanayi Kuruluşu Örneği. Yüksek Lisans Tezi. Sakarya: Sakarya Üniversitesi.

Nut, P. C. \& Backoff, R. W. (1992). Strategic Management of Public and Third Sector Organisations: A Handbook for Leaders. Jossey-Bass, San Fransisco.

Okay, Ş. (2009). Pamukkale Üniversitesi Öğretim Elemanlarının Üniversite-Sanayi İşbirliği Çalışmalarına Bakışları Üzerine Bir Alan Araştırılması. Selçuk Üniversitesi Teknik Bilimler Meslek Yüksekokulu TeknikOnline Dergisi, 8(2).

Papatya, G. (1998). Vizyon: Hayal ve Gerçek Arasındaki Gerilim. Süleyman Demirel Üniversitesi IIIBF Dergisi, 3(3).

Porter, M. E. (1996). What is Strategy?. Harvard Business Review, 74 (6).

Rachman, J. D., Mescon, H. M., Bovee, L. C., \& Thill, V. J. (1993). Business Today. New York: McGraw-Hill Inc.

Sakınç S., \& Bursalığlu A. S. (2012). Yükseköğretimde Küresel Bir Değişim: Girişimci Üniversite Modeli. Yükseköğretim ve Bilim Dergisi, 2(2).

Sánchez-Rodríguez, C., Martinez-Lorente, A. R., \& Clavel, J. G. (2003). Benchmarking in the Purchasing Function and its Impact on Purchasing and Business Performance. Benchmarking: An International Journal, 10(5), 457-71.

Şener, T. (2009). Eğitimde Stratejik Planlama. Yüksek Lisans Tezi. İstanbul: Kadir Has Üniversitesi.

Tortop, N., İsbir, E. G., Aykaç, B., \& Tosun, K. (1993). Işsletme Yönetimi. (1. Cilt) İstanbul: Fakülteler Matbaası.

U.Ü. Gelişim Planlama Kurulu (2002). Üniversitelerde Stratejik Planlama Rehberi. (Erişim: 02.02.2018), http://kurullar.home.uludag.edu.tr/GPK/SP_Guideline.h tm

Uzun, H. (2011). Yeni Bir Toplumsal Dönüşüm Sürecinin Üretim Birimi Olarak: Teknoparklar. Doktora Tezi. Elazığ: Firat Üniversitesi. 